\title{
INTRODUCTION LECTURE IN TRADING IN SECURITIES MARKETS AND ADVANCED MARKET MICROSTRUCTURE THEORY - THE ECONOMICS OF TRADING
}

\section{The aims of this lecture are:}

This lecture puts the topic of trading in securities markets into a bigger context of financial economics and relates the current topic to what we know about capital markets, asset pricing and behavioral finance.

The purpose of this introductory lecture is to show how important it is to understand the detail of the trading process in order to explain how securities markets are organized within international capital markets to provide price discovery, liquidity and lower costs of transacting and obtaining information.

To provide a more balanced argument regarding conceptions about trading as a zero sum game where behaviorally biased individual investors are taken advantage of by large institutional investors.

Having discussed these topics it should be clear to both professor and student that market microstructure has a theoretical rigor that has its place among the other areas of mainstream finance and economics. 
At the end of this lecture you should be able to answer:

- Why do we have secondary markets for financial assets where they are traded (ownership changes hands) continuously almost 24 hours a day?

- What are the main types of market participants and what are the objectives of their trading?

- What makes investors trade?

Source: Industry specialists and a famous academic study in Journal of Finance.

Investments is the study of the process of committing funds to one or more assets.

\section{Why Study Investments?}

- Most individuals make investment decisions sometime.

- Essential part of a career in the following fields: security analyst, portfolio manager, registered representative (broker/market maker), Certified Financial Planner, Chartered Financial Analyst, trader.

- Any level of expected return (ER) and risk can be attained.

Investors manage risk at a cost $=$ lower expected returns.
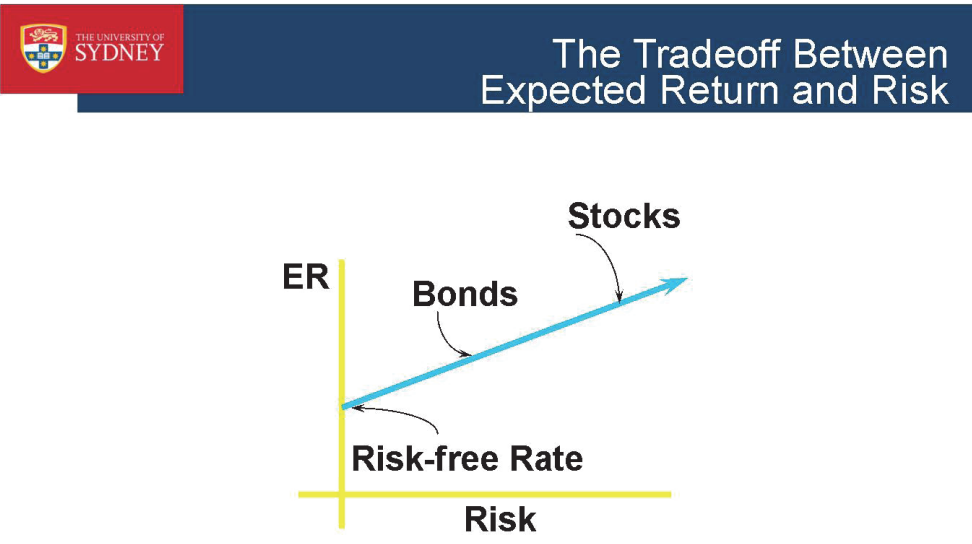


\section{A note from the finance professional}

\section{The investment decision is a two-step process:}

1. Security analysis and valuation of individual securities: necessary to understand security characteristics

2. Portfolio management

- Selected securities viewed as a single unit (portfolio)

- How efficient are financial markets in processing new information?

- How and when should it be revised?

- How should portfolio performance be measured?

\section{Investment}

objectives:

- Safety of Principal

- Growth of Principal

- Current Income

- Tax Protection

— Inflation Protection

Investment alternatives: Non-marketable Financial Assets

- Commonly owned by individuals

- Represent direct exchange of claims between issuer and investor

- Usually very liquid or easy to convert to cash without loss of value

- Examples: savings accounts and bonds, certificates of deposit, money market deposit accounts

Forms of risk

- Business Risk

- Financial or Bankruptcy Risk

- Liquidity Risk

- Political Risk

- Economic Risk

- Systemic Risk

\section{Money Market Securities}

- Short-term (<1 year), liquid, relatively low risk debt instruments

- Government bills, bank certificates and commercial paper

\section{Capital Market Securities}

- Marketable debt with maturity greater than one year and shares

Derivative Securities, Options,

Futures, Swaps and Hybrids 
Economic functions of Financial Assets: (1) transfer of surplus funds to those who need to invest in tangible assets (2) distribute the risk of cash flows generated by tangible assets.

Economic functions of Financial Markets: (1) determine the price and at the same time the required rate of return of Securities/Financial Instruments (2) provides a mechanism to sell Securities. (3) reduce the costs of transacting, search costs and information costs.

Globalization of Financial Markets: Entities seeking to raise funds need not be confined to the domestic market; investors are not limited to financial assets issued in their home country. Factors that have led to the integration of financial markets are (1) deregulation and liberalization, (2) technological advances for monitoring, executing orders and clearing in global markets, and (3) increased institutionalization of financial markets.

Financial Innovation: Since the 1960s there has been a surge in financial innovations:

1. Market broadening instruments, new opportunities to invest and borrow (junk bonds, leveraged buyouts (LBOs), hedge funds, exchange-traded funds (ETFs), algorithmic and high-frequency trading)

2. Risk-management instruments (futures, options, swaps, netted clearing)

3. Arbitraging instruments and processes. (FX arbitrage, arbitrage funds, merger arbitrage, pairs trading)

\section{Four principal financial product types}

\section{A. Equities}

common stock, preferred stock, warrants

\section{B. Fixed income securities}

some preferred stock, bonds, money market instruments 


\section{Derivatives}

options, futures, forwards, swaps, warrants

\section{Money}

currency and coins, deposits

We will focus on the top three in this course.

\section{Distinct Categories of Market Participants and the Purpose of their Trading}

\section{Financial Intermediaries (the sell side)}

- Investment banks, brokerage firms, market makers, dealers

- Purpose of their trading: market presence, brokerage, liquidity provision, facilitation

\section{Financial Institutions}

- See Frino and Segara (Table 1.1, p. 4) for market share of Australian institutions (e.g. Superannuation Funds, Public Unit Trusts, Life Insurance Companies, General Insurance Companies, Cash Management Trusts).

- Purpose of their trading: to invest funds for future pension or insurance payouts, lending and financing and hedging their portfolios.

Asset Management Firms, e.g. Blackrock around $\$ 3.8$ trillion under management!

- Purpose of their trading: Invest client fund actively or passively (index tracking) for management fees.

- Hedge funds: invest select large client funds aggressively for performance fees (examples later).

Financial Planners: Advice household clients on investments and tax.

Asset/Liability Risk Management: Concerns of regulators: (a) Credit Risk, (b) Counterparty Risk (counterparty fails obligation), (c) Liquidity Risk (counterparty late), (d) Market Risk 
(value-at-risk used to assess this risk), and (e) Operational Risk (failure of internal processes including legal risks) e.g. fraud, rouge traders.

\title{
Distinct Categories of Market Participants and the Purpose of their Trading
}

\begin{abstract}
Asset/Liability Problem of Depository Institutions: earn spread between loans and deposits, faces credit risk, regulatory risk (increased reserve requirements) and interest rate risk.
\end{abstract}

Commercial Banks: lending and servicing corporations

Savings and Loans Associations: lending and servicing households (US)

Savings Banks: lending and servicing households

Credit Unions: owned by members, low fee banking services for households, alternative to banks.

\section{Central Banks and the Creation of Money}

- Purpose: Maintain the stability of the currency and money supply for a country or group of countries. Bank of Japan: "To issue banknotes and to carry out currency and monetary control. To ensure smooth settlement of funds among banks and financial institutions. Currency and monetary control through price stability contribute to the sound development of the economy."

- The world listens very carefully when the Federal Reserve Chairman (Janet Yellen) speaks: Gives indications of what is going to happen to interest rates, very important for currency, bond and stock markets.

\section{Monetary Policy}

- Influences the supply of money through (1) imposing reserve requirements on deposit taking institutions currently, for example, on transaction accounts $12 \%$ and short-term deposits $3 \%$ in US, and (2) Open market operations: buying or selling government securities for reserve's own account. 


\section{Regulation}

Major Exchanges are to some extent self-regulated in the day to day monitoring of markets, but government regulators such as Securities and Exchange Commission (SEC) and Commodities and Futures Trading Commission, enact securities markets law and regulation.

\section{Distinct Categories of Market Participants and the Purpose of their Trading}

Insurance Companies: Life and General Insurance, important institutional investors, able to assess and take on long-term risks, now often blurred with banking as a result of mergers, can be highly profitable.

Investment Companies (mutual funds (US), investment funds (British)) and ETFs hold the largest proportion of funds under management in most countries. There has been a large increase in the proportion of individual's self-managed accounts recently.

- Allow investors to invest in shares/units in a diversified portfolio at low costs and leave the management of the portfolio to the fund; has gained in popularity.

- Investment funds are used by more hands-off investors.

- ETFs by self-managing investors, who can invest in all kinds of markets and financial assets through these funds.

\section{Pension Funds (Internationally) and Superannuation Funds (Australia)}

- The largest group of institutions in some countries (Australia: $>53 \%$ ).

\section{Important}

\section{THE MAJOR COUNTERPARTIES TO} INSTITUTIONAL INVESTORS ARE:

Corporations, listed and private:

- Transferring their risks and financing needs to investors through financial intermediaries

— Investing in tangible assets and businesses. 


\section{Private Individuals and Households}

- Investing savings and pension funds for future consumption

- Borrowing funds for housing and consumption.

- Sometimes households are as an aggregate group able to take on more risk and usually invest more long term than institutions

- Often takes the opposite side of institutional traders (either intermediaries provide liquidity to households or households provide liquidity to institutions).

\section{Connecting to Corporate Finance and other Common Finance Classes}

Pricing of Financial Assets: Price = PV (future cash flows)

The Level and Structure of Interest Rates: Driven by outlook of economy, currency supply/demand and central bank manipulation of interest rates.

The Term Structure of Interest Rates: Short-term rates affected by monetary policy, long-term rates based on market expectations.

Risk/Return and Asset Pricing Models: CAPM, Black \& Scholes, the Cost of Carry Model.

LEARN MORE IN CORPORATE FINANCE, DERIVATIVE SECURITIES AND FIXED INCOME UNITS OF STUDY!

We will be using these models to price futures and options when we look for mispricing (arbitrage opportunities) in this unit.

\section{A note from the finance professional}

What are the incentives that drive investors/traders? Important distinction:

A. Trade to take advantage of short-term movements in asset prices

OR

B. Invest to create a well-diversified portfolio that provides the expected rate of return at the suitable level of risk. 
Do not mix the two, never leave a trade in the portfolio just because it did not work and try to justify it as a long-term investment for diversification!

1. Decide what your purpose for trading in the market is, shortterm speculation, diversification, value, arbitrage, hedging, liquidity provision

2. Device a strategy: Fundamental, Technical, Momentum, Contrarian

3. No clear purpose for trading, no clear strategy will lead to losses! IF SO:

4. Invest in the index - leverage for more risk, make fixed income deposit for less risk. ETF on index is today the most affordable way of indexing!

\section{What Are Behavioral Biases and Who is Impacted?}

Grinblatt and Keloharju [2001] study a large sample of investors of all types, institutions, households, corporations, government and non-profit organizations.

They analyze determinants of buy and sell transaction in a large sample of investors and find that

- Past Returns (larger positive past return is positively related to sell decision)

- Reference Price (purchase price affects the decision to sell)

- Capital Gain or Loss (reluctant to take large losses, too eager to take small profits)

- Length of Holding Period (longer holding period less affected by reference price and past returns)

— Tax Loss Selling

- The smoothing of consumption over the life cycle

are ALL determinants of the decision to trade, households being more biased.

Concludes that current theoretical models are not sufficient to explain these behavioral biases. 


\section{Are Individual Investors and Households Uninformed?}

Recent research has found that the classical view that individual household investors are naive, noise traders appears incorrect.

- In the short run (1 month), households are rewarded for providing liquidity to institutions (Leung, Rose and Westerholm [2012]; Kelley and Tetlock [2012]; Grant, Mills and Westerholm [2014]).

- In the long run (>1 year), contrarian households are rewarded for being on the opposite side of asset pricing bubbles like the tech boom of 1998/2000 and the Global Credit Crisis (2007/2009) (see Westerholm, Swan and Lu [2014]).

- Institutional fund managers follow the signal of aggregated retail buys-sells and are trading profitably around the world on this signal (Financial industry source [2012]).

\section{Is Investing and Trading a Zero Sum Game?}

It has been argued that trading is a zero sum game, for you to be able to make a profit someone else has to lose this money to you. When trading is costly, this would lead to most traders losing money!

This is not quite true, in the short run, say one trading day if all traders opened their positions in the morning and closed them at night, then the wins would sum up to the losses less costs (day traders, short-term FX trading, highly leveraged margin trading in shares).

Investors and traders have many diverse reasons for trading and very different holding periods, hence it is possible that one trader takes a short-term loss, but benefits from the risk transfer to another trader who makes a short-term gain for taking on this risk.

There are also situations when all/most traders are better off, for example, when the share markets rise due to better profits from corporations, this benefits both short- and long-term traders (while those that have bet on falling prices make a loss in the shortterm at least).

What investment/trading strategy one follows is a very personal choice. 


\section{What Trading Strategy Will You Use?}

Disclaimer: The instructors of this unit of study are not licensed to give you investment advice and you should consult a registered financial advisor in case you are interested in becoming engaged with investing and trading in securities. Information about how to find a financial advisor can typically be found on the website of Securities Exchanges and the market regulators.

Stock Brokers and Futures Market Participants Australia

\section{Examples of Typical Trading Problems}

\section{Retail trades}

An individual investor Jane has $\$ 6,000$ to invest. It is Friday July $24,2015$.

Jane thinks the upcoming earnings released by Facebook (FB) is going to be a good news and wants to add FB to her portfolio, and decides to buy 50 shares. Stock is trading around $\$ 96.95$, up by 1.51 from the close the previous day.

- Solution: enter a limit buy order to buy 50 shares at $\$ 96.95$ into the online brokerage system. The value of the trade if executed is $\$ 4,847.5$.

Jane also thinks that her portfolio needs to contain search engine and software giant Google, but thinks the stock is quite expensive, $\$ 623$ a share, she can afford only one share.

- Solution: enter an order to buy one (1) September 625 call option and to write $(-1)$ September 650 call option. This is a bull spread with the following investment and payoff. These options expire on September 18, so there is a limited time for this investment, and all invested capital is lost if the share stays at current level or falls in price.

- Investment: outlay: $1 \times 22.50$ (contract price) $\times 100$ (underlying shares $)=\$ 2,250$, income: $1 \times 10.00$ (contract price) $\times 100=$ - $\$ 1,000$, total investment $\$ 1,250$ plus commissions.

- Payoff: if share goes above 650 by September 18 .

$$
650-625=25 \times 100=\$ \mathbf{2 , 5 0 0},
$$


profit $\$ 1,250$ less commissions (if you bought one stock at $\$ 623$ and sold at $\$ 650$ profit is $\$ \mathbf{2 7}$, with lower risk and no time limit!).

\title{
Fundamental Information is Very Important for Investors and Traders
}

\begin{abstract}
Investors get important cues for future cash flow and growth from earnings releases. Some speculate on the direction of the actual release compared to expectations, as surprises may lead to drastic price changes.

Zacks Equity Research: Social networking giant Facebook, Inc. (FB) was set to report its second quarter 2015 earnings on July 29,2015 . While the company reported a negative surprise of $4.17 \%$ in the previous quarter, it is noteworthy that over the preceeding four quarters it had a positive earnings surprise of $2.05 \%$. It had outgrown many industry majors to be in the league of Google GOOGL and Amazon.com Inc. AMZN. (http://finance.yahoo.com/ news/facebook-earnings-glow-amzn-nflx-201408179.html)
\end{abstract}

Options quotes can be obtained from, for example, Yahoo Finance. Traders usually use their broker's online trading platform for this purpose.

\begin{tabular}{lcccc}
\hline & & & & OPEN \\
& BID & ASK & VOLUME & INTEREST \\
\hline Sep 2015 625 CALL & $\mathbf{2 1 . 7 0}$ & $\mathbf{2 2 . 5 0}$ & 58 & 241 \\
Sep 2015 650 CALL & $\mathbf{9 . 0 0}$ & $\mathbf{1 0 . 3 0}$ & 25 & 100 \\
\hline
\end{tabular}

Examples of Typical Trading Problems

Institutional trades

The portfolio manager of an institution Super Fund Plc wishes to increase the weight of Newcrest Mining (ASX: NCM) — one of the largest gold mining stocks - in their portfolio by $3 \%$ as the gold price has started to rise. The institution is currently holding 1 million shares worth 19.3 million AUD. 
Solution:

- The Super Fund's trader James would pull up the online access system IRESS they have through one of the many brokerage firms they use for their investments to see what the current situation in NCM is, he sees (OVERLEAF):

- At 3 p.m. in the afternoon, 2,797 shares at 19.38 and 1,000 at 19.47 .

- James quickly estimates that they need to purchase $0.03 \times 1$ million $=30,000$ shares of NCM. At the moment the depth at the best offer price is only 2,797 shares!

- James calls up one of the Institutional Investment Bank (say UBS) they use to find out what is the best they can offer 10,000 shares of NCM at.

- James also calls his contact at Macquarie Bank and asks them to put in an order for 30,000 shares of NCM into the Australian Stock Exchange dark pool (CENTRE POINT).

Why? What is James trying to achieve? Why doesn't he buy what is available in the market, about 5,000 shares? Why does he ask for 10,000 shares only? Why two brokers? What is a dark pool?

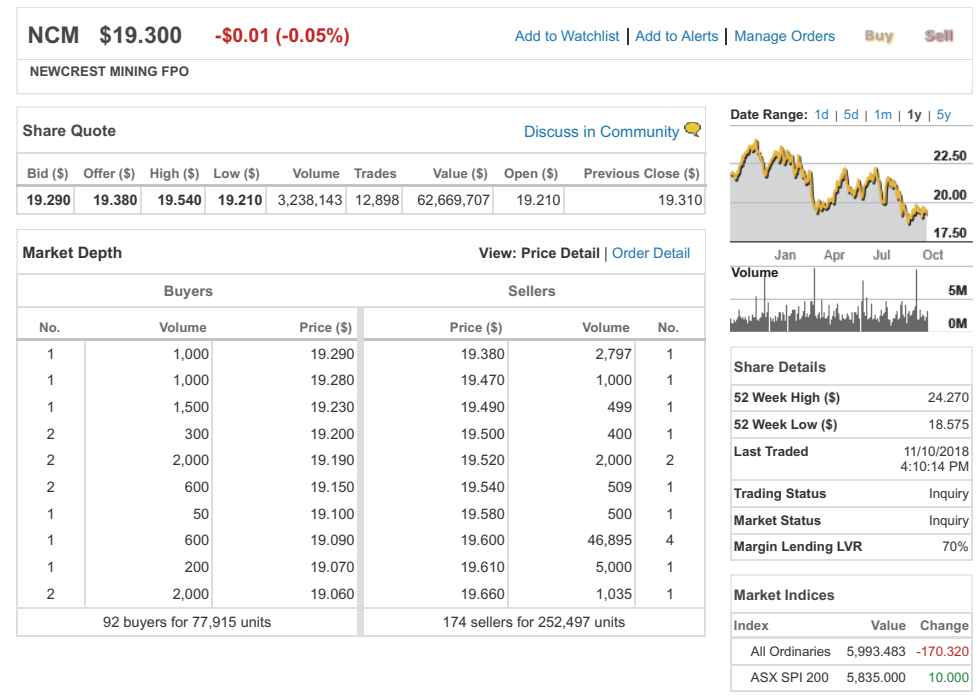




\section{Why?}

- What is James trying to achieve?

Minimize the market impact of his relatively large order (the order size is approximately $1 \%$ of the daily volume of 62.8 million dollars in total).

- Why doesn't he buy what is available in the market, about 5,000 shares?

James decides it is not wise to directly start buying in the market as this may temporarily lead to higher prices for the some of the stocks he is trying to buy.

- Why does he ask for 10,000 shares only from UBS?

James does not wish to expose his full interest to one broker as this may provide him with a better price as UBS does not see how much he really needs (remember these tactics may have negative impact on the relationship between broker and customer if misused).

- Why two brokers?

It is always good to have several brokers competing for your business to maximize price improvement.

- What is a dark pool?

One of the latest options in trading venues is to route orders to a dark pool where orders can be executed with less exposure to other traders, and hence may receive price improvements as compared with the "lit" main ASX market where all orders are visible pre-trade.

\section{Wealthy and Successful Entrepreneurs}

To gain a perspective of wealth: Who is/was_Wealthier?

\section{John D. Rockefeller}

In 1870, he founded the Standard Oil Company and ran it until he officially retired in 1897. By the 1880s, Standard Oil Company's share of the world oil refining topped out above $90 \%$ but slowly dropped to about $80 \%$ for the rest of the century. 
By 1937, John D. Rockefeller had a personal wealth of $\$ 1.3$ billion. He was the world's first billionaire.

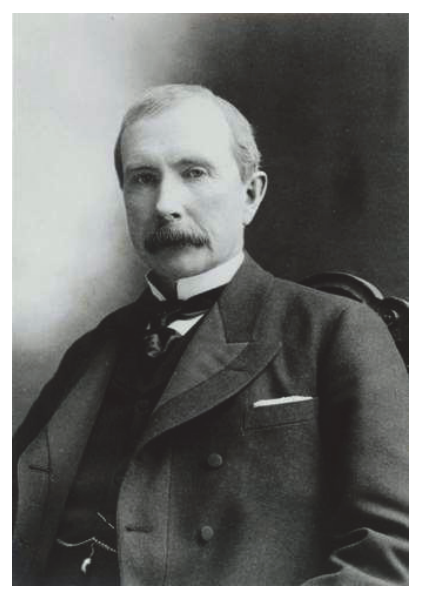

\section{Bill Gates}

In 1975, he cofounded Microsoft and ran it as CEO until he officially retired in 2000. Microsoft is one of the world's largest software companies with revenue of $\$ 93.58$ billion in 2015 .

By 2015, Bill Gates had a personal wealth of $\$ 79.2$ billion. He is hence one of the world's richest people.

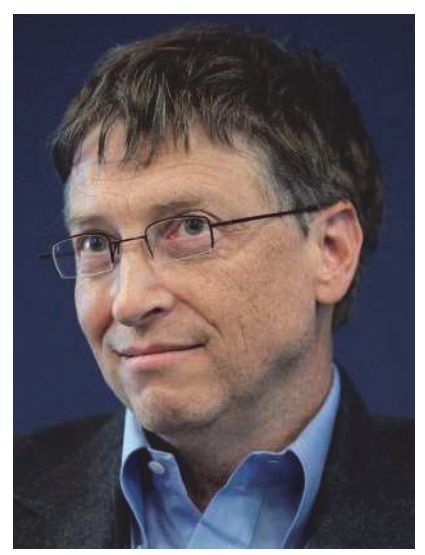




\section{Is Bill Gates richer than Rockefeller?}

John D. Rockefeller is considered by many to be the wealthiest person ever. If he was able to maintain his wealth at the rate of inflation, which has averaged $3.6 \%$ p.a. in nominal terms since 1937 , then by 2015 his wealth would have been $\$ 21.8$ billion. Given his wealth comprised mainly common stock, he might have been able to maintain it at the rate of return of the S\&P Composite Index, which since 1937 has averaged $9.55 \%$ p.a. in nominal terms, then by 2015 his wealth would have been $\$ 1.6$ trillion.

COMPARE Bill Gates (Microsoft) - $\$ 90$ billion
Jeff Bezos (Amazon) - $\$ 112$ billion

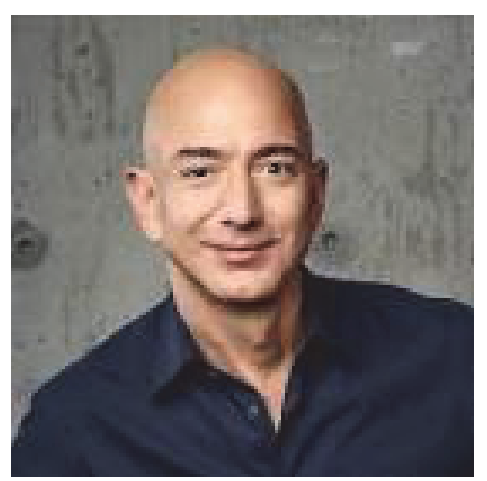

Warren Buffet (Berkshire Hathaway) — \$84 billion

The most well-known investor Warren Buffett (1930-)

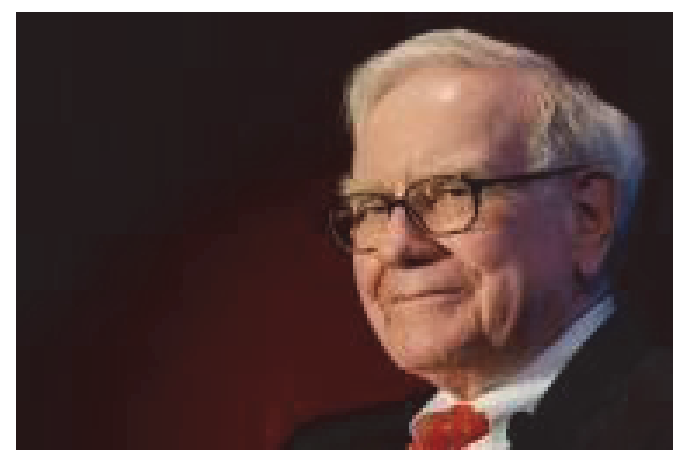


$\$ 90,192,000,000$ under management

Personal Net Worth: 2018, $\$ 84$ billion (\#3)

Holdings:

(http://www.cnbc.com/id/22130601)

- Wells Fargo

- Coca Cola

- IBM

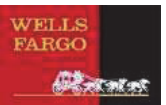

Coabola

- American Express

- Procter and Gamble

- Wal Mart Stores

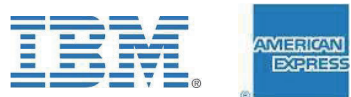

Berkshire Hathaway Stock: (BRK.A fianance.google.com)

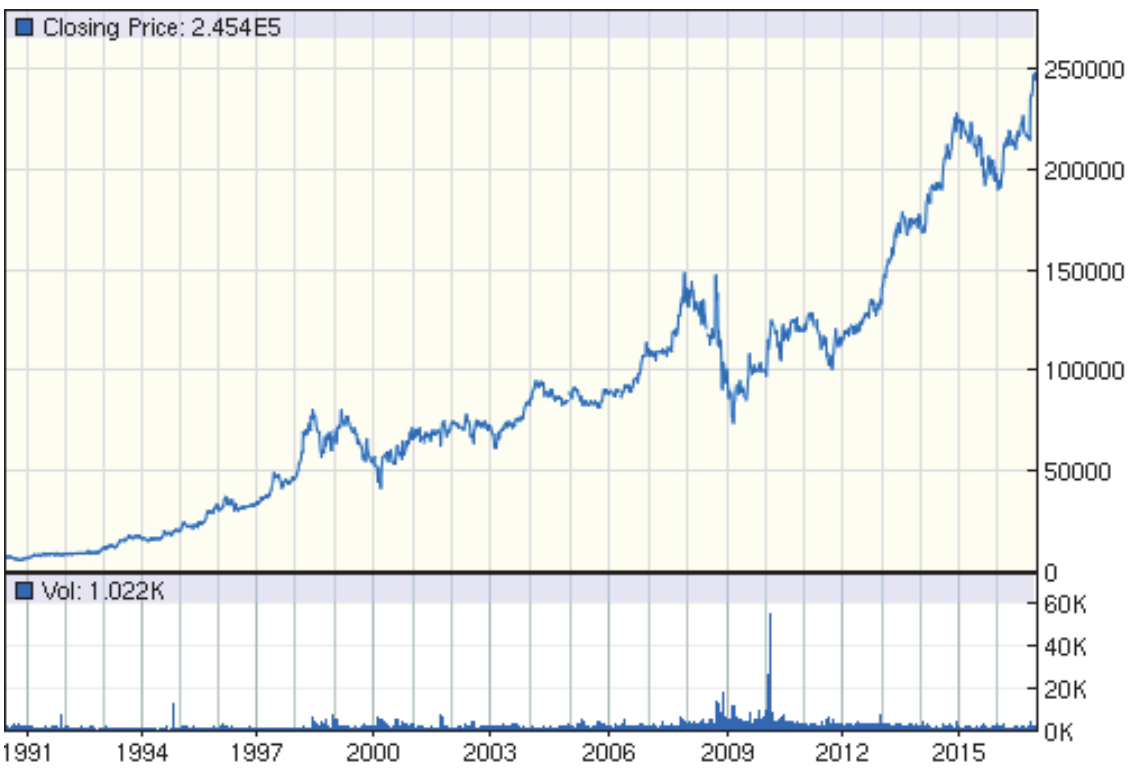

Traders and Hedge Fund Managers

One of Jones' earliest and major successes was predicting Black Monday in 1987, tripling his money during the event due to large short positions. Paul Tudor Jones II (1954), is the founder 
of Tudor Investment Corp., private investment partnerships, also referred to as hedge funds.

The industry standards are $2 \%$ p.a. of assets under management and $20 \%$ of the profits, Tudor Investment Corp. charges $4 \%$ p.a. of assets and $23 \%$ of the profits.

Contrarian attempt to buy and sell turning points.

Keeps trying the single trade idea until he changes his mind, fundamentally. Otherwise, he keeps cutting his position size down.

He trades the smallest amount when his trading is at its worst.

Considers himself as a premier market opportunist. When he develops an idea, he pursues it from a very-low-risk standpoint until he has been proven wrong repeatedly, or until he changes his viewpoint.

Swing trader, the best money is made at the market turns. Has missed a lot in the middle, but catches a lot tops and bottoms. Estimated net worth in 2018 was $\$ 4.5$ billion (Forbes).

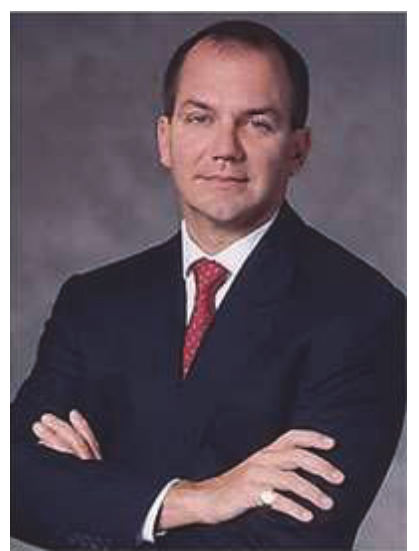


James Harris "Jim" Simons is an American hedge fund manager, mathematician and philanthropist (1938-).

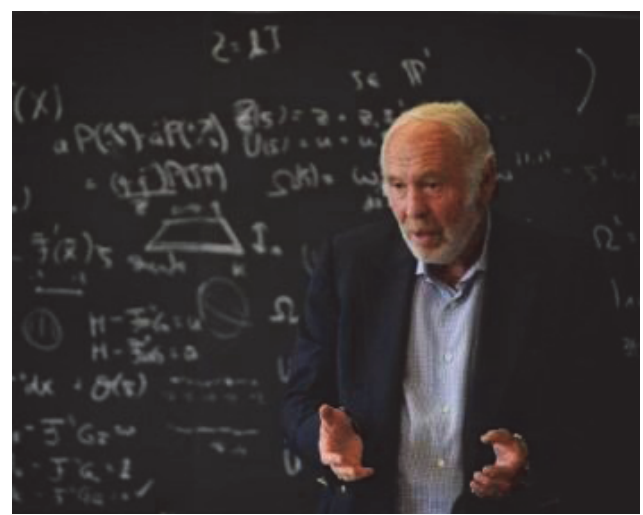

His trades average typically $+100 \%$ p.a.!

In 1982, Simons founded Renaissance Technologies, a private investment firm based in New York with over $\$ 15$ billion under management. Simons retired at the end of 2009, as CEO, of what is widely considered the world's most successful hedge fund. Simons' net worth is estimated to be $\$ 14$ billion (Forbes, underestimation?).

Simon's fund Medallion employs high frequency trading and exploits inefficiencies in the stock market. One strategy they use takes advantage of the inefficiencies in the execution of large transactions. One of their algorithms determines whether a very large order is executed and front runs it. As a result Medallion experiences high transaction costs and high expenses. That is why they charge a $5 \%$ fixed fee. On top of that they charge performance fee. That fee had been $20 \%$, but after 2000 it increased initially to $36 \%$ and then to $44 \%$ !

The world's richest hedge fund manager though is officially George Soros with net worth $\$ 24.9$ billion! 


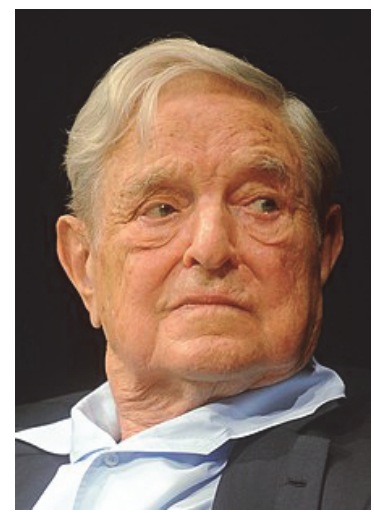

Soros, "broke" the bank of England trying to defend the pound, predicted and profited from the Asian crisis, orchestrated a number of other famous trades.

LET US STOP TALKING AND START EXPERIENCING WHAT TRADING IS ABOUT!

\section{Start up your computer!}

Form groups of three to four students

LOG IN to your trading simulation program and follow the instructions from your Professor. 